\title{
Education and Research Concept for College Innovative Music and Dance
}

\author{
Song Guo \\ School of Music \\ Dalian University \\ Dalian, China
}

\begin{abstract}
With the deepening of college education reform, music and dance education in Chinese colleges has undergone a new development. But the colleges are still restrained by the traditional ideology in terms of teaching concept, and the teaching mode is too old. This paper has discussed in-depth the innovation of music and dance teaching mode, and the problems existing in current music and dance education, as well as the innovation strategy and the construction of dance teaching evaluation system, and has proposed new ideas about music and dance education innovation.
\end{abstract}

Keywords -music and dance education; innovative teaching mode; teaching quality evaluation system

\section{INTRODUCTION}

The colleges in China are the base for cultivating various professional. However, colleges' concept toward music and dance education directly influences China's cultivation level of music and dance professionals. Under the new situation of continue reform of college education system, the teaching mode of music and dance shall also be innovated constantly. Colleges shall find out the problems existing in current teaching, to change teaching concept, and add new teaching idea, thus to cultivate the moral and intelligent professionals with high-quality and meeting social demand.

\section{CATER TO SOCIAL DEMAND AND INNOVATE TEACHING MODE}

Under the situation of continuous development of China's economy and society, the development mode of college music and dance education shall cater to social demand. The development and innovation of college music and dance education is not only the need for professional development, but the main factor determining the development of music and dance education should be the social demand. Music and dance education shall follow the teaching law, and adjust the relationship between music and dance teaching and social demand in combination with the realistic demand of the society. The innovation of teaching mode shall research and analyze the demand of current social demand and economic construction for music and dance professionals with emphasis, realize the social function and social value of music and dance, as well as adjust and plan the teaching based on the development trend of social market and professional fields. Colleges shall change the traditional teaching mode and establish a new teaching system adapting to the society, only in this way, can the compound professionals meeting social demand and having strong ability, high quality and wide caliber be cultivated, thus to render a long-term development to the music and dance specialty in China's colleges.

Colleges shall also pay attention to the cultivation of students' creative ability of music and dance, work out the creative plan of key plays, and construct the decision-making mechanism for the creation of key plays. Colleges shall give play to the local students' advantages in combination with the local cultural characteristics, and make field tour and practice, to create the artistic works with local culture and distinctive features. The creation of works shall be able to reflect the requirements of the program, so that students can understand that the creation of music and dance needs the foundation of life and good environmental conditions. The creation of music and dance shall have some exploratory breakthroughs in some major areas and key issues, and focus on the cultivation creative spirit. Colleges shall establish a good brain circulation flow mechanism, strengthen talent cultivation and exchanges, to provide reliable guarantee for the cultivation of students' creation ability. Music and dance education in colleges shall also pay attention to the aesthetic education on students, to enhance students' ability of understanding, appreciating and creating beauty, and to cultivate their correct aesthetic standard; focus on the cultivation of students' moral sentiments, which are all belonging to the teaching category of college music and dance education. Aesthetic education on students can enhance their self-confidence, cultivate their noble ideological quality and moral character, and lead the students to a higher realm of art and to have a higher level of spiritual pursuit. In the music and dance education in colleges, we shall pay attention to joint management of music and dance professional knowledge, skills training and aesthetic education, to render students a comprehensive development of their professional skills, physical and mental health and comprehensive quality.

\section{ANALyZE THE PROBLEMS EXISTING IN EDUCATION AND PROPOSE CORRESPONDING STRATEGIES}

Colleges haven't understood music and dance education fully. Music and dance education in colleges is to cultivate students' professional knowledge, and promote the comprehensive development of their physical and mental health as well as moral sentiments. However, the current music 
and dance teaching in colleges lays too much emphasis on the cultivation of students' professional skills, while ignoring the cultivation of aesthetic ability and practical ability, hindering students' overall development, making music and dance education lose its original meaning. Colleges haven't paid sufficient attention on the learning of comprehensive cultural knowledge. The current admission score of music and dance specialty in colleges is too low, which limits students' development in the future. The majority of the students after enrollment only focus on professional knowledge learning, having no interest in cultural courses, resulting in students' low cultural knowledge and comprehensive quality decline. Cultural quality is the foundation of one's artistic cultivation and attainment. With low cultural level, colleges have difficulties in cultivating the professionals with high quality, which is bad for students' overall development in the future. Without good cultural knowledge, it is hard to have a higher development even if more time is spent on professional skills training. In the current social situation, what the society needs are the practical talents with high quality. However, in the current setting of music and dance courses in colleges, 90 percent is the professional theory learning and skills training. And most of the practices organized by colleges are arranged uniformly with centralized guidance, and there is little chance of actual operation, which is bad for the cultivation of students' practical operation ability. In addition, most students believe that they can make a difference as long as they learn the professional knowledge very well, but ignore the courses of Chinese and History which can improve their cultural deposits and art accomplishments, affecting students' overall development.

Therefore, teachers should update their concept, to guide students understand music and dance education in-depth, to enable students to understand the learning of cultural knowledge and the exercising of professional theoretical knowledge and skills supplement each other, culture and skills promote each other, forming an indivisible whole. Teachers should use verified teaching methods and means to create a relaxed learning environment for students, enabling students to appreciate the charm of music, feel the artistic enjoyment brought by dance. Meanwhile, they shall pay attention to help students accumulate artistic experience, cultivate students sense of art. For example, as for dance, students can only create dance with high proficiency when they have certain accumulation of dance movements, and find out the change rule for further innovation and development. Such as: the works of "Folding", the director has made a perfect combination of the eastern and western dance movements while creating it. Integrate the western physical expression characteristics of shape showing and extrovert into the creation of works, and at the same time, skillfully make the rounders of Chinese classical dance run through the whole flow of the dance, making the audiences feel the fish's happy playing in the water. The slow rhythm of entire dance makes people have a surreal quiet feeling. There wouldn't be such a wonderful idea if the director has not profound movement accumulation of Chinese classical dance and Western modern dance.

Colleges need to innovative teaching mode to improve students' comprehensive cultural quality. In order to improve students' overall quality and enable to them to have an overall development, colleges shall adopt the comprehensive teaching mode of giving priority to professional teaching of music and dance supplemented by multi-disciplinary teaching, enabling students to expand artistic horizons and improve overall quality. College teachers should help students to recognize that music and dance teaching is not just the learning of professional skills, but the learning of history, literature, and philosophy is the foundation for cultivation of artistic talents with high quality. Teachers should help students to establish a correct outlook on life and noble moral qualities, which are the artistic accomplishment needed by the current social development. In teaching, teachers should pay attention to the cultivation of exploratory innovative and intelligent talents, break through the traditional narrow-minded thinking that only focuses on the cultivation of professional skills, constantly improve students' theoretical accomplishments, to enable students to have a higher theoretical level, which helps to improve students' level of professional knowledge, so that students may have higher artistic accomplishment. Teachers should also pay attention to individualized cultivation of students, encourage students to make personalized development, fully explore their inner potential, cultivate students' spirit of independent thinking and independent exploration, and pay attention to cultivate students' practical operation skills, to improve the overall quality of students.

\section{CONSTRUCT EVALUATION SYSTEM AND ORGANIZE INNOVATION RESEARCH}

From the development trend of China's higher education system, the construction teaching quality evaluation system is an important measure to promote art education, which can make the teaching of music and dance develop toward the scientific, democratic and synthetic direction. College evaluation system can guide multiple subjects of the colleges participate in the education quality evaluation, to enable the college education quality system to achieve optimization and upgrading. The creation of evaluation system of music and dance teaching can make real-time supervision on school's education management and teaching level, thus to promote the reform and innovation of music and dance teaching. Adjust and reform the teaching courses through the feedback of evaluation system. And the construction of teaching evaluation system can also enable the teachers realize the shortcomings and defects in teaching and to make recommendation and adjustment in a timely manner, rendering students a more perfect learning platform and making them recognize and feel the artistic charm of music and dance better. The construction of evaluation system of music and dance education can make multi-angle determination of students' learning condition, thus to provide reasonable suggestions for teachers' teaching. Ability evaluation shall not only check students' theoretical knowledge level, but shall pay more attention to the cultivation of students' practical abilities. When teachers are leading students participating in social practice, they shall set relevant problems regularly to check students' ability of actual operation and affairs processing. 


\section{CONCLUSION}

The construction of education quality evaluation system of schools is to improve the education quality in schools. The use of advanced teaching and education concept renders students more knowledge and better development. Teachers shall evaluate teaching methods according students' specific conditions, and analyze multiple factors such as interest in learning and their results, and reflect the defects of teaching mode form students' learning condition. Teachers shall adjust the teaching plan in a timely manner according to evaluation results, so as to improve the teaching quality of music and dance teaching, in order to improve students' artistic quality and overall quality, thus to cultivate the comprehensive artistic talents with high quality.

\section{REFERENCES}

[1] Yang Tongjun. Discussion on College Music Education Innovation [J]. Big Stage, 2014, (6):16-17.

[2] Chen Shubai. New Mode of Music and Dance Development in Higher Vocational Colleges [J]. Hunan Agricultural Machinery, 2013, (9): $168+170$.

[3] Wang Peng. Analysis of Necessity of College Dance Education Innovation [J]. Notonly Music, 2015, (12): 101. 